\title{
Alexandru-Cristian DUMITRACHE* \\ Shades of Fake News: Manifestation, Effects and Ways to Combat False Information
}

\begin{abstract}
In a continually changing global political environment, fake news has become a widely debated topic by both researchers and ordinary people. Despite the relevance and the diversity of approaches, few studies have focused on the typology of fake news in specialised scientific literature, while proper assessment methods and detection techniques are not well-established yet. This paper addresses the complex concept of fake news, presenting its significance and highlighting its different types, from propaganda to news satire; the moderators of the fake news effects and the ways to counter disinformation. This exploratory study reveals that solutions to combat the phenomenon exist, but they focus more on effects rather than on causes, leaving space open for further research.
\end{abstract}

Keywords: fake news, disinformation, moderators of fake news effects, media trust, public trust

\section{Introduction}

In a world of constant change, information plays a crucial role. Information explosion is a recent phenomenon determined by increased information production and by improved access and exposure to it (Abbott, 1999). As more and more of the world's information moves online and becomes digitised, information becomes accessible to anyone, anywhere with little restrictions related to time, costs, language or geography.

In a digital society, people from different parts of the worlds can communicate in seconds. Moreover, using social media platforms, anyone can transmit and promote different kinds of data to a specific audience.

All the facts mentioned above, along with the continuous evolution of technology (artificial intelligence taking over different types of communication) led to permanent worldwide information exchange, to which people are addicted. Whether talking about information on friends, family or directly on the news and what is happening 'out there', people always feel the urge to refresh the flow of data. The news is that part of communication that keeps peo-

${ }^{*}$ National University of Political Studies and Public Administration (Romania), ac.dumitrache@yahoo.ro 
ple informed of the changing events, issues, and characters in the world outside (Dean, 2013). The news media also functions as an indirect source of knowledge about one's epistemic community (Gelfert, 2018).

Many people follow daily news and the main problem addressed is related to the news consumers ability to distinguish between the real and potentially false information provided as "the selection of topics must have sufficiently broad appeal" (Gelfert, 2018, p. 89). In this respect, it is difficult to recognize if information delivered by news media is accurate and the actual potential effect of the spread of false information on people are yet to be discussed.

Despite many attempts to define and characterize the fake news phenomenon by journalists, commentators or scholars, a clear distinction between multiple forms or types of public disinformation has not been achieved to date. Additionally, the academic literature on the "fake news' topic lacks in presenting a concrete typology of the concept (for exceptions see Tandoc et al. (2018), Wardle (2017)). Therefore, this paper tries to explain the phenomenon of 'fake news' presenting its shades and sides as well as the ways it can manifest, while discussing its possible effects on specific audiences and ways through which it can be combated.

\section{The roots of a globally spread phenomenon}

False news is written and published with the intention of misleading people, for different purposes: from doubting or tarnishing the reputation of institutions or individuals to diverting attention from an event or getting advertising revenue.

Although the spread of false information or rumours seems to date back to ancient times, serving mainly political interests, these practices have expanded at various scales after the emergence of newspapers and journalism.

In the 19th century in the USA, Erwin Wardman, the editor of New York Press, used for the first time the term 'yellow journalism', describing a model of journalism that presents not very well documented news and relies on attractive titles to sell more newspapers (Vivian, 2002). The consequences of this type of sensational journalism practised in the USA have been long time subject of debate for American historians, newspaper propaganda on the Cuban crisis being considered a triggering factor for the Spanish-American war, 1895-1898 (Auxier, 1940).

While the yellow journalism of the 1890s and tabloid journalism of 1920-1930 have led to many criticisms and even to the stigmatisation of the press, the need for establishing norms and adopting a code of ethics becomes increasingly obvious (Gajda, 2009). The 'Code of ethics for the Newspapers', adopted by the Kansas Editorial Association in 1910 have established for the first time standards, regulations and responsibilities for journalists (Hill, 1922). The changed attitude of public and court towards the press has contributed in a way to the rise of real news, generally increasing the accuracy and responsibility of the written media and particularly increasing the credibility of notable newspapers.

Although diffusion of false news is not new, the proliferation of this phenomenon is closely associated with the Internet, and the development of high-tech platforms followed by the migration of media business almost entirely to the online world. These changes brought back again the issue of false or exaggerated news, produced and distributed this time 'on-clicking'.

The term 'fake news' has been around since the 19th century, but its popularity started to grow in 2016, along with two key events in the near history: the Leave vote for Brexit and the election of Donald Trump as President of the United States of America (Bârgăoanu, 2018). 
These events highlighted the increasing power of new communication channels while traditional media continues to lose both influence and money (Newman, 2017).

Presently, despite the existing precedents and similarities in mass-media history, these new challenges related to fake news are becoming much more difficult to overcome. Social media users are assaulted by fake news; however, few studies are focussing on the structure of social media networks and how the presence of fake news might affect the degree of misinformation and polarisation in a society (Azzimonti \& Fernandes, 2018).

The Internet has changed the global framework in such a way that ordinary people now understand terminologies such as fake news, echo chambers, like factories, social bots, troll diplomacy or filter bubbles (Bârgăoanu \& Radu, 2018).

The misinformation diffusion network and its foremost purveyors are challenging to control: massive amounts of fake news have spread over social media before and after the 2016 US Presidential Elections, despite intense fact-checking efforts (Shao et al., 2018). Individuals, with different social characteristics, much more frequently mention the term 'fakes news' public debates about their effects taking place everywhere. Even news agencies themselves started discussing the concept of 'fake news' and its consequences, often even arguing and pointing the finger at each other with accusations of false information production. As an example, articles concerning the topic of fake news are often published in the international edition of the 'New York Times' newspaper or in issues of the 'TIME' magazine.

The so-called 'consequences' of fake news are starting to appear all over the world and different kinds of measures are taken to combat the situation: in Germany, for example, Angela Merkel's cabinet voted a law proposal that would fine social networks with up to 50 million euros for failing to remove what could be defined as 'fake news' (Cuthbertson, 2017); in Indonesia, the communications minister wants to hold weekly news briefings, with the goal of countering fake news (Meixler, 2018). In France, President Emmanuel Macron also tried to find legal solutions against fake news, even though trying to separate truth from fiction from a legislative point of view was seen as a way to strengthen censorship (Alouane, 2018). 'BuzzFeed News' even made an analysis which showed that, during the presidential campaign in the United States in 2016, news categorized as fake generated more engagement, in the last three months prior to the election, than so-called 'trustworthy' news publications such as 'Washington Post' or 'NBC News' (Silverman, 2016).

According to 2018's Reuters Institute Digital News Report, ordinary people started raising questions about fake news in a different way than the previous year, as politicians and press representatives use the term much more often. However, even though people are worried about fake news, they encounter difficulties when it comes to pointing out a proper example of what is fake news (Newman, Fletcher, Kalogeropoulos, Levy, \& Kleis Nielsen, 2018).

Many studies claim that 'fake news' has been around since forever, but the question is how this concept changed in nature during the last years. Press agencies (and especially partisan press) have frequently published and distributed articles that contain incomplete or false information. On the other hand, 'fake news' can no longer be analysed as something that only regards the press, since the social context is one where the media continually change and new ecosystems of news appear, with the help of the Internet (McGonagle, 2017).

However, 'fake news' managed to become a wide debated concept during what many researchers use to call the 'post-truth' era (Keyes, 2004). This era could be a consequence of a few powerful trends, among the global population, that can be developed or that could be 
linked to different extremist or radical political movements, which can better rely on ideology, instead of concrete evidence (Lewandowsky, Ecker, \& Cook, 2017).

'Fake news' became a powerful concept because the topic itself has roots in this post-truth era, which has been built on strong pillars. Firstly, one of the main reasons for the development of this era is the decrease of social capital. Studies have shown that, since 1970, especially in the United States of America, factors like goodwill, trust in public institutions, empathy and even the willingness of someone to share a secret with anyone else, have decreased considerably. Another strong pillar on which the post-truth era is based refers to increasing inequalities between people, which has driven the masses to have different strong attitudes according to their living standard. Also, another factor can be the constantly increasing political polarisation, some studies describe how people tend to relocate themselves in communities that share, more or less, the same ideologies. Likewise, other causes for this era to develop can also be the declining trust in science and the politically asymmetric credulity, which refers to the fact that someone's susceptibility to misinformation can be related to that person's political orientation. Without any doubt, the strongest pillar of the post-truth era is the evolution of the media landscape. This factor changed significantly during the last years, which could be explained in various ways: first of all, social media created the 'echo chambers', where the information is distributed according to the user's opinions and beliefs. Second, the development of new media also favoured a wider range of choices regarding the information that can be consumed, which provided a safe environment for the spread of biased opinions. Moreover, people can now talk over the Internet even though there are vast distances between them. This factor contributes to impoliteness which, afterwards, favours a stronger division between those with different opinions. Lastly, the fact that the media are fractioned allows strategic extremism to be engaged by different personalities (Lewandowsky et al., 2017).

Therefore, it seems that one of the means that permitted the development of fake news can undoubtedly be the evolution of the social media platforms, within which anyone can create shareable content and transmit it to huge audiences (Tarran, 2017). As an example, with the help of a website, of social media platforms and with many fake written reviews, someone managed to get a restaurant to be 'number one' on the TripAdvisor rankings in London, even though that restaurant does not exist, and no one visited it. The hoax was strongly mediatised on the internet afterwards, being an example of how people can be influenced by good public relations (Butler \& Clifton, 2017).

In other words, some of the changes that made people perceive fake news in a stronger way were based on the fact that fake news can be produced in a very sophisticated manner, at a large scale and with incredible rapidity and effectiveness. Technology made it possible for almost anyone to create and distribute such content in many possible forms, such as texts, photos, videos, memes, etc. (McGonagle, 2017).

The new technologies are not only contributing to the development of fake news, but they can also help with their propagation. The spread of false news was frequently compared to the transmission of infectious diseases. An interesting fact to notice is that viruses, exactly like rumours, need a host and dense population to spread and that opinions, like certain diseases, form on social contacts. In this regard, it seems that studying the ways that this transmission of infectious illnesses takes place can provide data on how misinformation is distributed among the population (Kucharski, 2016).

However, mass-media are the most affected by the phenomenon of fake news. Whether the media is accused of creating it or it has to suffer from the concept itself, people's trust in 
mass-media has certainly decreased over the last years. A raft of initiatives over so called 'fake news' from both publishers and platforms fail to restore public trust (Newman, 2017).

As an example, the Edelman PR Agency investigates population's level of trust in different institutions around the world. This agency has set up the Edelman Trust Barometer, a survey aiming to asses the level of confidence that the population of a country has on various topics or institutions such as the Government, the business environment, the NGOs or the mass-media and how this level changed over time. According to this research, which addressed over 33,000 respondents, the level of trust in mass media decreased worldwide, within almost all the analysed countries, the latest values dropping below 50\% (Table 1). As well, results highlighted the divergence in trust between the informed public and mass population, while both parties share an urgent desire for change. (Edelman, 2018) 
Table 1. Countries' level of trust in mass-media.

\begin{tabular}{|c|c|c|c|c|c|c|c|}
\hline & 2012 & 2013 & 2014 & 2015 & 2016 & 2017 & 2018 \\
\hline Argentina & $47 \%$ & $50 \%$ & $49 \%$ & $45 \%$ & $53 \%$ & $40 \%$ & $39 \%$ \\
\hline Australia & $33 \%$ & $32 \%$ & $36 \%$ & $34 \%$ & $42 \%$ & $32 \%$ & $31 \%$ \\
\hline Brazil & $52 \%$ & $55 \%$ & $50 \%$ & $51 \%$ & $54 \%$ & $48 \%$ & $43 \%$ \\
\hline Canada & $50 \%$ & $53 \%$ & $57 \%$ & $52 \%$ & $55 \%$ & $45 \%$ & $49 \%$ \\
\hline China & $73 \%$ & $71 \%$ & $68 \%$ & $64 \%$ & $73 \%$ & $65 \%$ & $71 \%$ \\
\hline Columbia & & & & & $55 \%$ & $45 \%$ & $43 \%$ \\
\hline France & $37 \%$ & $40 \%$ & $37 \%$ & $39 \%$ & $38 \%$ & $33 \%$ & $33 \%$ \\
\hline Germany & $39 \%$ & $51 \%$ & $51 \%$ & $45 \%$ & $44 \%$ & $42 \%$ & $42 \%$ \\
\hline Hong Kong & $54 \%$ & $55 \%$ & $55 \%$ & $50 \%$ & $47 \%$ & $42 \%$ & $43 \%$ \\
\hline India & $60 \%$ & $70 \%$ & $64 \%$ & $70 \%$ & $63 \%$ & $66 \%$ & $61 \%$ \\
\hline Indonesia & $68 \%$ & $73 \%$ & $69 \%$ & $68 \%$ & $63 \%$ & $67 \%$ & $68 \%$ \\
\hline Ireland & $35 \%$ & $34 \%$ & $36 \%$ & $31 \%$ & $39 \%$ & $29 \%$ & $33 \%$ \\
\hline Italy & $50 \%$ & $45 \%$ & $43 \%$ & $41 \%$ & $50 \%$ & $48 \%$ & $45 \%$ \\
\hline Japan & $33 \%$ & $34 \%$ & $38 \%$ & $30 \%$ & $38 \%$ & $32 \%$ & $32 \%$ \\
\hline Malaysia & $46 \%$ & $58 \%$ & $51 \%$ & $46 \%$ & $45 \%$ & $42 \%$ & $47 \%$ \\
\hline Mexico & $56 \%$ & $57 \%$ & $53 \%$ & $48 \%$ & $58 \%$ & $47 \%$ & $48 \%$ \\
\hline Netherland & $53 \%$ & $52 \%$ & $55 \%$ & $54 \%$ & $55 \%$ & $54 \%$ & $55 \%$ \\
\hline Poland & $40 \%$ & $38 \%$ & $35 \%$ & $38 \%$ & $34 \%$ & $31 \%$ & $34 \%$ \\
\hline Russia & $32 \%$ & $33 \%$ & $33 \%$ & $42 \%$ & $38 \%$ & $31 \%$ & $35 \%$ \\
\hline Singapore & $61 \%$ & $62 \%$ & $60 \%$ & $55 \%$ & $60 \%$ & $54 \%$ & $52 \%$ \\
\hline South Africa & & & $45 \%$ & $41 \%$ & $45 \%$ & $39 \%$ & $35 \%$ \\
\hline South Korea & $42 \%$ & $47 \%$ & $44 \%$ & $41 \%$ & $43 \%$ & $40 \%$ & $40 \%$ \\
\hline Spain & $43 \%$ & $43 \%$ & $42 \%$ & $42 \%$ & $49 \%$ & $44 \%$ & $44 \%$ \\
\hline Sweden & $30 \%$ & $36 \%$ & $34 \%$ & $28 \%$ & $31 \%$ & $33 \%$ & $32 \%$ \\
\hline Turkey & & $28 \%$ & $19 \%$ & $18 \%$ & $23 \%$ & $25 \%$ & $30 \%$ \\
\hline U.A.E. & $51 \%$ & $58 \%$ & $59 \%$ & $62 \%$ & $59 \%$ & $44 \%$ & $56 \%$ \\
\hline United Kingdom & $32 \%$ & $36 \%$ & $37 \%$ & $33 \%$ & $36 \%$ & $32 \%$ & $32 \%$ \\
\hline S.U.A. & $37 \%$ & $38 \%$ & $35 \%$ & $39 \%$ & $47 \%$ & $47 \%$ & $42 \%$ \\
\hline
\end{tabular}

Source: 2018 Edelman Trust Barometer.

These findings are consistent with other studies which point out that people are starting to wonder what is fake and real in the news. This aspect is more visible in countries such as the United States or Brazil, where the use of social media is mixed with political polarised situations, rather than in countries like the Netherlands or Germany (Newman et al., 2018). 


\section{Defining fake news and its shades}

Recent studies which are focussing on this topic attempt to define and clarify the concept (Gelfert, 2018). However, there is no consensus yet on a generally accepted definition of 'fake news'. Many researchers used this term in their papers outlining the differences between fake news and false news or disinformation, but the conclusion that comes out is that the concept has many shades and could be defined from several perspectives. An analysis of the articles that investigate the fake news (Figure 1) concluded that the phenomenon is circumscribed to six different forms of manifestation, more precisely: propaganda, news satire, news parody, news fabrication, photo manipulation and advertising, and public relations (Tandoc, Lim, \& Ling, 2018).

Figure 1. Typology of fake news, according to Tandoc et al. (2018).

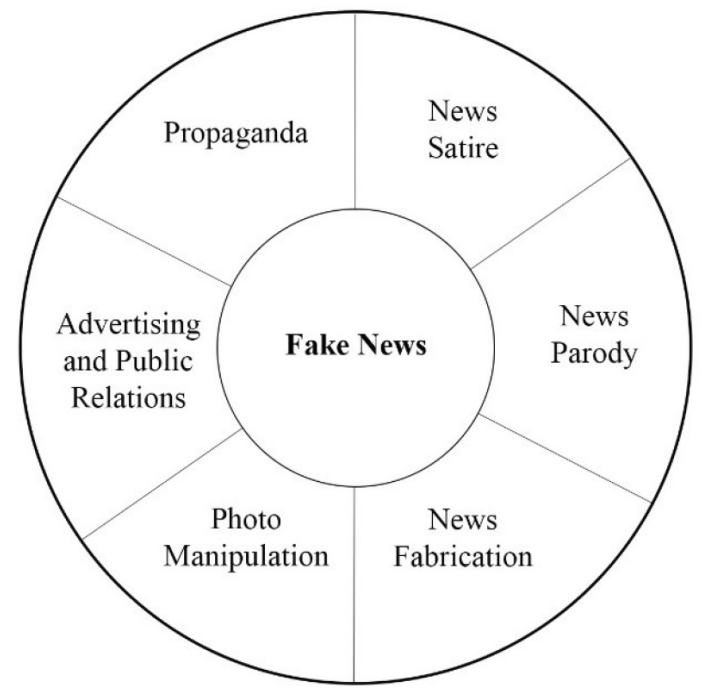

Despite some similarities, most of the authors agree that fake news is different from propaganda. Fake news refers to different kinds of information presented as authentic but, in reality, they are only partially real or are exaggerated to the point that they become false. Furthermore, the purpose of fake news is to mislead or to deceive a particular public, and its structure is fluid and adaptative. Thus, it can consist of information that is real but is presented in such a way that the overall information is fake, or the text can be accompanied by pictures that have no actual relationship with the narrative presented. Propaganda, on the other hand, can be described in two different ways: one type of propaganda is the transparent one, where both its intentions and its source are made public and its purpose connects to influence a target audience in a positive manner. The other kind of propaganda refers the one that hides its source and motives, and that is targeted to an audience which is not aware of the fact that it is manipulated (Reilly, 2018).

Up until this point, propaganda could seem similar to 'fake news'. The difference is that the latter became so strong because its transmission is not necessarily facilitated by statecontrolled media agencies or by governments or by certain media organisations, they can be redistributed by simple individuals using the Internet and social media, even without them realising it (Reilly, 2018). However, the substantial similarity between propaganda and fake 
news is that both are based on facts which are promoted as objective but are presented only from one side or perspective, with the purpose of persuading the targeted audience, rather than informing it (Tandoc et al., 2018).

On the other hand, the 'News' format of television programs is widely used at an international level, making it also one of the most parodied types of content. This phenomenon is globally enlarging, but little is still known about the causes of its occurrence in various countries with different cultures, traditions or political systems (Baym \& Jones, 2012). However, even if some researchers consider the term can be an umbrella that can cover many aspects, the concept of news satire is different from news parodies. News satire represents a widespread form of fake news, because it uses types of humour and many exaggerations to present actual news. A good example of TV shows that use this form of content is the Comedy Central show or The Daily Show. News satire programs and tv-shows are based on the presentation of current information displayed in a way that generates laughter among its audiences. These shows are embodied in the context of an actual news bulletin, with a frontman sitting behind a desk; the difference is that the anchor is not presented as a journalist or as an investigator but as an entertainer or a comedian (Tandoc et al., 2018). The key element involved in the production and distribution of news satires is its influences on the targeted audience. Some studies have shown that the opinions and beliefs of particularly younger publics can be influenced and even changed by this kind of shows. It seems that college students that watch news satire TV shows are more likely to have negative attitudes towards specific political personalities. Also, studies have shown that individuals without an active interest in politics or news information developed a specific curiosity on different subjects debated on the public agenda after viewing those particular topics presented on news satire TV shows. This kind of shows is considered by certain audiences to have the role of simplifying the news from the public agenda and reformulate them in such a way that they become understandable to everyone (Brewer, Young, \& Morreale, 2013).

However, Balmas (2014) considers satirical content as one of the forerunners of fake news, describing it as a way to emphasize the negative aspects of the political events of the day, in a humorous way, portraying political figures as egotistical, phoneys or incompetents. Noteworthy is that his study shows how the exposure to such content can potentially influence its viewers attitude towards the political agenda or various party men.

Similar to the news satires, news parodies represent another form of fake news. The latter can take many different forms: "from faux news anchors who posture authoritatively at pretend news desks, to puppet shows, sketch comedies, and panel discussions" (Baym \& Jones, 2012, p. 4).

However, news parodies hold a strong likeliness to the news satires because the information presented in it has the same use of humour and exaggeration. Also, when providing specific data to an audience, the shows make use of the same type of format as the actual TV news bulletins, with a frontman that sits behind a desk while presenting what is new.

A key element that makes news parodies different from news satires is the fact that parodies use facts and information that is already false, when trying to induce humour to its audiences. News satires have their starting point on something that is true, only for the data to be changed afterwards into something that is only partially correct, with the help of humour and exaggerations (Tandoc et al., 2018). An interesting example of a news parodies website can be The Onion which, with the use of a nicely built web architecture and a carefully written content, has sometimes passed in the minds of specific publics as an actual truthful news 
website. This kind of fake news detains a particular type of strength due to their capacity to be seen as presented by a variety of journalists that can hold accountable other common journalists. They come on top in the process of news sharing, since regular media agencies transmit particular information and news parodies websites take that information and turn it into something different in a humorous way, while denigrating the image of specific journalist and media organisations (Berkowitz \& Schwartz, 2016).

Furthermore, news parodies and news satires are around for a longer while than the emerging of Saturday Night Live type of TV shows. This content dates back to the occurrence of comic commentary on the radio. On television, however, this genre became popular around 1960', when shows like That Was The Week That Was or This Hour Has Seven Days aired, with content having an interesting blend between satirical content and actual news reportages (Day \& Thompson, 2012). Nonetheless, this type of humorous content is appealing especially to younger audiences, half of the target group that fancy this programming genre being under 30 years old. Thus, some researchers have come to the conclusion that such content can strongly influence young adults into having lower levels of trust in Government (Hoffman \& Young, 2011).

Another way through which fake news can be operationalized is the process of news fabrication. Fabricated news is different from news satires and news parodies due to its method of presenting false information as a truthful press agency does. However, the substantial difference between fabricated news and news parodies is that between the latter and its audience there is, frequently, a silent agreement upon the fact that the presented information is fake, and its only purpose is fun. Fabricated news, on the other hand, has only one goal which is to misinform its publics (Tandoc et al., 2018). For a stronger outcome, fabricated news websites often use web domains which sound similar to the ones owned by certain real media agencies and present fake news as it would be documented and real information posted by that particular media organisation. However, it seems that this kind of websites have a short lifespan. As an example, more than a hundred sites for fabricating news which were extremely active during the United States of America 2016 Elections no longer exist (Allcott \& Gentzkow, 2017). The US 2016's Elections sparked a global conversation among researchers on the topic of news fabrication and its impact on the electoral action plans. However, studies have shown that fabricated content does not resonate well with audiences and it is not addressed to everyone. Even though it is used for various political reasons, its purpose is not to convert people of a certain political orientation to another or to influence undecided individuals to choosing a side, but to strengthen the passions of already partisan audience groups (Mourăo \& Robertson, 2019).

Fake news can also manifest through the false narratives created by the manipulation of specific visuals and videos. Controversy around this topic is not new and photography manipulations containing text additions or modifications are something relatively easy to make, in a way that looks authentic. That is one of the reasons many researchers leaned over this situation and studied the ways in which a photo can be determined to be fake or not, by analysing if newly added content to a picture violates the precise rules of perspective projection (Conotter, Boato, \& Farid, 2010).

The techniques and methods used in the process, on the other hand, widely vary, starting from simple modifications like the tone or the saturation and colours of a picture to editing it to the point where certain individuals appear or disappear from the photo. This type of fake news scattered quickly since the software for creating such visual modifications is available 
to almost anyone (Tandoc et al., 2018). This technique, however, can also be used differently: a photo or a video that is indeed authentic can be accompanied by a narrative text that also consists of accurate information, but has no actual relationship with the visual support that is used. This method is not only used by media agencies, but it can also be accessed by nonjournalists that have access to different audiences through social media. With the nowadays social media network's algorithms, a text accompanied by a photo is better rated on the publics' news feeds than a simple news article. However, even though computer generated visuals are highly popular and widely used in advertising, cinema or in the gaming or TV shows industry, when it comes to journalism, photographers and photo-reporters have to obey a set of strict rules that forbid the alteration of the visual content. On the other hand, technology in this field evolved at such a rapid pace, that even experts in this domain find it hard to distinguish between authentic photos and computer-generated visuals (Lehmuskallio, Häkkinen, \& Seppänen, 2018).

The last form of fake news in Tandoc et al. (2018) typology can be described using the advertising and public relation domains. This method consists of a public relations or advertising agency writing a specific article about a particular product or, if the need arises, of a political personality or a specific concept which is published, afterwards, by a news agency as an article written by journalists, without necessarily specifying the source of the narrative to the audience. However, this method of advertising is considered as fake news especially for the fact that "without disclosing the source of the message, the marketers are violating principles of transparency and the consumers' right to be informed by whom they are persuaded" (Nelson \& Park, 2015, p. 337). In the Russian Federation, researchers write about a clear distinction between the black and the white public relations. While, according to the code of ethics used, white PR represents the transparent way of communication, the techniques previously described can be associated with the black PR, which consists of manipulative techniques used during electoral campaigns (Tsetsura, 2009). Other studies show that these methods can not be classified as public relations at all, because they have all the means of being propaganda (Tulupov, 1996).

However, other authors use a different typology of fake news. In Wardle's (2017) opinion, fake news does not exist on its own, the term being widely used for concepts that have different meanings and origins. Therefore, in elaborating another typology of fake news, three pillars were used (mostly based on the content that is shared to an audience): the first criterion relates to the types of content used in the process of information sharing, the second one is based on the creation motives of the content creators (intention to deceive) while the third pillar consists of how this content is further distributed (Wardle, 2017).

Thus, Wardle (2017) distinguishes seven types of fake news and orders them using a scale based on the intention of the content creator to deceive (figure 2). Similar to Tandoc et al. (2018) typology of fake news, satirical (parodied) content and fabricated content are on the list with a key difference: satirical or parodied content is situated on the lowest point of the intention to deceive scale, while fabricated content is placed on the highest spot. The other elements on the intention to deceive scale (rated from the lowest to the highest) are, as it follows, false connection (commonly known as clickbait, or when there is a discordance between the image or the headline used for a news article and its content), misleading content (when information is used in a misleading way with the purpose of framing an issue), false context (when genuine information is used in an unrelated context with the purpose of misleading the audience), imposter content (when phoneys make use of or pose as veridical 
sources of information) and manipulated content (when genuine information or visuals are manipulated to serve for a different purpose).

Figure 2. Typology of fake news, according to Wardle (2017).

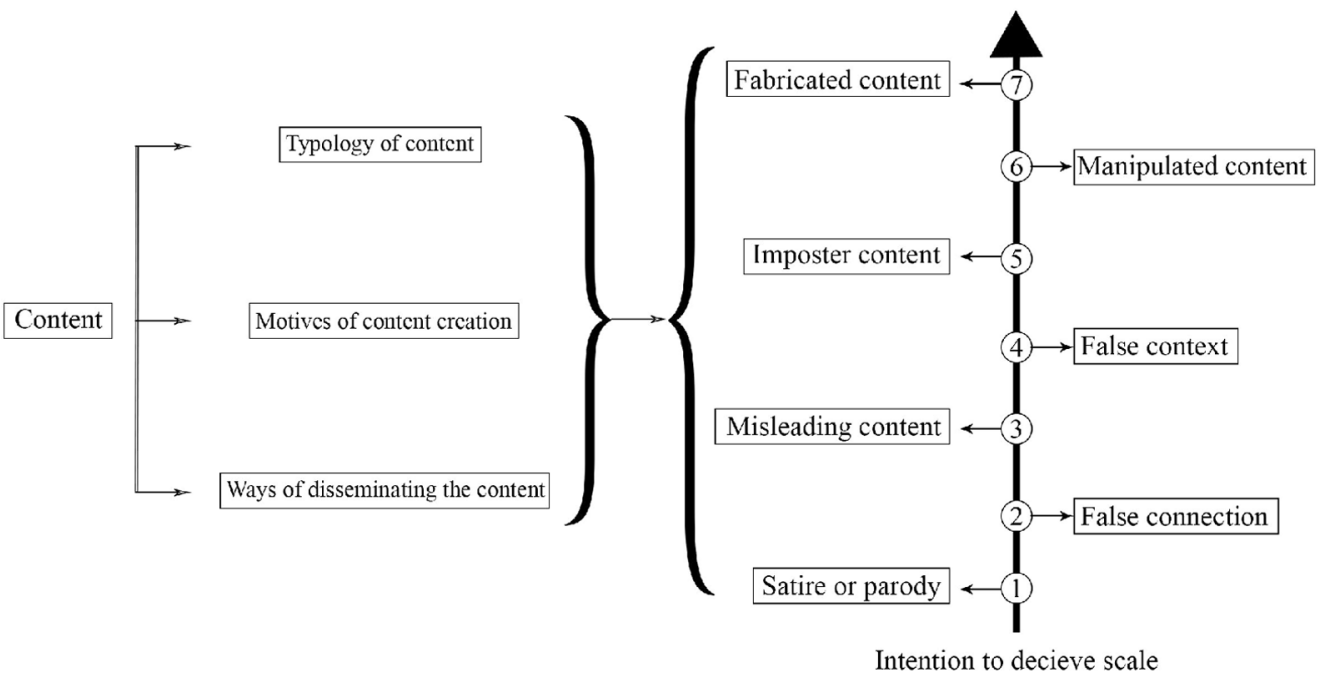

\section{Effects and moderators of fake news effects}

The concept of fake news can have many sides and shades, having a lighter or a stronger presence in a certain visual or written narrative. However, an essential aspect of this domain consists of the effects that it can have on its audiences and the variables which moderate these effects. Fake news can influence people in various ways, affecting individuals' attitudes towards politics through political inefficacy, political alienation or cynicism towards political candidates (Balmas, 2014).

Political efficacy refers to an individual's conviction that he/she can understand the current political landscape and can actively participate in it (Niemi, Craig, \& Franco, 1991). However, political efficacy consists of two sides: one of them refers to the perceived competence, which represents the ability of an individual to understand the political agenda, while the other refers to the perceived effectiveness, which is the individuals' belief that their actions can change the shapes of politics (Balmas, 2014).

Political alienation, on the other hand, is a consequence of the political inefficacy feeling and it mainly represents someone's beliefs that its actions cannot change in any way the political agenda. However, the feelings of political alienation can take four different shapes, each one having different potential influences on an electoral campaign or on the views towards a political personality: political powerlessness, which refers to one's conviction that he/she cannot change the political doings, political meaninglessness, which refers to the unpredictability of the political actions, perceived political normlessness, related to one's beliefs that the states laws are inefficient and political isolation, referring to the denial of the current state laws widely accepted (Finifter, 1970). 
On the other hand, political cynicism is related to individuals' loss of trust in politicians or in their actions. Thus, this cynicism is associated with a general restraint towards the political landscape, often related to the perceived incompetence or immorality of political personalities (Šram, 2016).

According to Balmas (2014), the dangerous effects of misinformation lie in fake news' very ability to strongly influence these three elements, which can be vital to the outcome of an electoral campaign. Thus, it seems that changes in individuals' attitudes towards politics via political inefficacy, political alienation or cynicism towards political candidates can particularly be discovered within individuals who perceive fake news as real. However, noteworthy is that Balmas (2014) only considers satirical and parodied news content as fake news, partially because his study was published before the political events leading to the vivid academic and public debate about "fake news".

However, studies have shown (Alonso-Muñoz \& Casero-Ripolles, 2018) that the content of a message can also determine its capacity to become viral. In other words, viralisation is another fake news effect. A proper example is the intensive use of Twitter by Donald Trump during his 2016 electoral campaign: his popularity grew significantly not because of the enormous amounts of tweets posted, but because of their content, which was widely distributed by both citizens of the United States and the press (Pérez-Curiel \& Naharro, 2019).

In this regard, it seems that the public itself plays a significant role. Very often, people who have been exposed to fake news can play a bridge role between the false information and an even wider public, by sharing and distributing what they witnessed in the media. A strong moderator of fake news effects is, therefore, the very audience that is exposed to false information and the cognitive ability of the individuals that form it. An audience is created by many individuals and every person can react differently when exposed to fake news. Some researchers have shown that according to someone's level of cognitive ability, certain false information can have a stronger influence. In this regard, it seems that people with a lower level of cognitive ability are influenced by fake news to the point that even if they see proper evidence that the information was fake, they still find it hard to believe that the previous report was not accurate. In other words, the influence of fake news on such individuals can have untreatable consequences (De keersmaecker \& Roets, 2017).

Timing can also be a moderator of fake news effects: For instance, studies have shown that, in a group, if the audience is exposed to false information before they have the chance to witness the accurate news or, at least, discuss it with each other, the impact can be stronger than if the public firstly sees the truthful information (Spinney, 2017). People are more likely to believe fake news if the first information that they are exposed to on a particular topic is fake than if false information comes after the distribution of accurate information.

Moreover, the effects of fake news can also relate to the Third Person Perception: some researchers have pointed out how a group of partisan citizen can believe that a group of a different political orientation is more exposed to the dangers of fake news and find it more difficult to protect themselves from disinformation (Jang \& Kim, 2018). Similarly, in Romania, studies have shown that the theory of the Third Person Effect can apply to this context as well. Thus, people have a tendency to believe that distant others are more influenced by fake news than themselves (Ștefăniță, Corbu, \& Buturoiu, 2018).

Another moderator of fake news effects is age. Many adolescents, for example, started taking their information from places different than the actual source. The evolution of technology made them access social media for getting the news, rather than reading the newspaper 
or watching the news bulletin on TV (Marchi, 2012). According to the Reuters Institute Digital News Report of 2018, for the last 7 years, the use of social media for news was constantly growing. However, due to recent changes in algorithms, Facebook is not the only social media channel relevant in this matter: the use of WhatsApp for news almost tripled for the last 5 years, while managing to overtake Twitter in importance in some countries (Newman et al., 2018). Another source of information for adolescents is what their friends share on the social networks and the comments section of different posts, where people randomly argue on specific news. Moreover, news parodies and satires represent a leading source of information for this age category. In the presented context, studies show that adolescents already have a preference for opinionated news, rather than dull and accurate information (Marchi, 2012). In other words, age can moderate the individual's capacity to perceive fake news as accurate, according to its will to believe and further distribute already opinionated content without checking its source.

The format in which fake news is embodied can also be a moderator of its effects. Studies have shown that viewers of satirical or parodied content have a more comprehensive knowledge of the news agenda than those who watch televised news only, as the blend of seriousness and humour is a reliable source of information, satisfying two types of gratifications: the need of entertainment and the need of information (Browning \& Sweetser, 2014). The problem is that fake news can infiltrate much easier within a transmitted opinion about a piece of information that within the information itself. Not least, news literacy could play an essential role. The Digital News Report of 2018 which measured for the first time the level of news literacy show that people with higher level of news literacy tend to prefer newspapers brands over TV and use social media for news very differently from the wider population (Newman et al., 2018). In this respect, elevating the degree of information literacy of the audience should be one of the education goals. Thus, public ability to judge the quality and veracity of news content will improve (Anderson \& Rainie, 2017).

\section{Fighting fake news}

The audience plays, therefore, a significant role on the distribution and the effects of false news. That is certainly a reason why many researchers interested in the field design further studies to focus more on the role of the public and on its behaviour.

This could explain why a proper method of fighting fake news does not target the way they are created or distributed, but instead focuses on the way that the audience reacts to it. Understanding the way that people respond to fake news can hold the key to diminish the phenomenon properly (Spinney, 2017).

In January 2018, a High-Level Expert Group (HLEG) with the sole purpose of advising the European Commission on matters such as fake news and online disinformation was set up. Furthermore, while hinting to the dangers of fake news that can reach all parts of society, the phenomenon poses a threat to democracies themselves, by altering election processes and public policies. Thus, the HLEG came up with a set of possible solutions to the matter which, nonetheless, need further testing. The solutions consist more of an action plan, based on five connected pillars. The first one refers to enhancing the transparency of online news, while the second one is based on promoting media literacy. The third one relates to creating tools to enable journalists and media users to counter disinformation and the fourth refers to 
supporting an environment where the diversity and sustainability of the European news media can further develop. The last pillar relies on promoting continuous academic research on the subject (High Level Expert Group on Fake News and Online Disinformation, 2018).

Other solutions are rather small and refer to concrete and precise methods of fighting parts of the problem, or effects of the problem, but not fake news itself. One such way can be on the sides of the public institutions, who would have an obligation to communicate and distribute accurate information very often (Spinney, 2017), in such a way that fake news would become a reactive phenomenon and not remain a proactive one.

Another possible solution lays in the hands of technology: fake news also makes its way to the public by using 'social bots', which are different algorithms used in social media to make a specific account look like a real one, used by a real person, but is, in fact, just a bot programmed to act according to a specific interest. In this regards, platforms for checking the accuracy of social media profiles started to appear (Davis, Varol, Ferrara, Flammini, \& Menczer, 2016).

A third possible way to fight fake news refers to how media agencies and state officials respond to the phenomenon. A proper answer could consist in the way that precise information is wrapped. An effective way to combat false information could be to distribute truthful details in such a way that people will want to believe it and will be willing to discard the fake news, by using emotions or a call to feelings (Tarran, 2017).

Nonetheless, social media platforms came up with new techniques, adapted to the contemporary misinformation spread status, to counter fake news: Facebook, for example, invested in updated technology and human resources to better handle the fake accounts situation. Up to this day, Facebook is continuously working with fact-checkers to ensure that problematic content is taken down (Newman, 2019), while in France, during the last three years, the malicious and suspicious content on the network was cut down to a half (Senecat, 2018).

Another social platform that has taken measures against fake news is WhatsApp. In order to counter the dissemination of false information, the application has reduced the number of times individuals can forward a message from 250 to 20 (Newman, 2019). Even though it is not widely used, in countries such as India, WhatsApp became a tool of mass disinformation: forwarded messages containing various fake news have been the starting point of many violent incidents. Upon an enquiry made by the Indian Government, WhatsApp created, for the first time, a televised campaign on 'how to protect yourself' from spam and fake news disseminated in the forwarded messages on the application (Thaker, 2018).

YouTube and Twitter are also working on the matter. While the video-sharing platform is implementing measures to prioritise trustworthy news sources rather than breaking news or conspiracy videos, Twitter has managed to introduce new ways of identifying bots, verifying approximately nine million accounts a week (Newman, 2019).

\section{Conclusions}

Fake news became a critical concern worldwide, which may have severe consequences at many levels. The topic is debated on many platforms and almost all the news agencies, which are firstly accused of fake news, discuss and share opinions on the diffusion mechanism as well as on the consequences of misinformation. 
Fake news spread in many shapes and sizes and methods of detecting and combating this phenomenon are challenging. Also, the concept is difficult to define, since shades of fake news can be found in news parodies, news satires, propaganda, news fabrications, photo manipulations, advertising and public relations, etc.

Beyond academic or public debates, research studies focusing on the effects of fake news aim at assessing the impact of the phenomenon or discovering tools to detect, control and combat fabrication or diffusion of false information. While the role of social media in spreading false information should not be underestimated, a better understanding of human behavior and improving audience literacy level could represent essential steps to reducing impact or effects. As studies focus mostly on the effects of disinformation and not on its causes, further research targeting this dimension needs to be conducted.

\section{References}

Abbott, R. (1999). The World As Information. United Kingdom: Intellect Books.

Allcott, H., \& Gentzkow, M. (2017). Social Media and Fake News in the 2016 Election. Journal of Economic Perspectives, 31(2), 211-236. doi:10.1257/jep.31.2.211.

Alonso-Muñoz, L., \& Casero-Ripolles, A. (2018). Communication of European populist leaders on Twitter: Agenda setting and the 'more is less' effect. El Profesional de La Información, 27(6). doi:10.3145/epi. 2018.nov.03.

Alouane, R.-S. (2018). Macron's Fake News Solution Is a Problem. Retrieved November 7, 2018, from Foreign Policy website: https://foreignpolicy.com/2018/05/29/macrons-fake-news-solution-is-a-problem/.

Anderson, J., \& Rainie, L. (2017). The Future of Truth and Misinformation Online | Pew Research Center. Retrieved March 30, 2019, from https:/www.pewinternet.org/2017/10/19/the-future-of-truth-and-misi nformation-online/.

Auxier, G. W. (1940). Middle Western Newspapers and the Spanish-American War, 1895-1898. Journal of American History, 26(4), 523-534. doi:10.2307/1896320.

Azzimonti, M., \& Fernandes, M. (2018). Social Media Networks, Fake News, and Polarization. Retrieved February 17, 2019, from https://ideas.repec.org/p/nbr/nberwo/24462.html.

Balmas, M. (2014). When Fake News Becomes Real: Combined Exposure to Multiple News Sources and Political Attitudes of Inefficacy, Alienation, and Cynicism. Communication Research, 41(3), 430-454. doi:10.1177/0093650212453600.

Bârgăoanu, A. (2018). \#FAKENEWS: Noua cursă a înarmării. Bucharest: Evrika Publishing.

Bârgăoanu, A., \& Radu, L. (2018). Fake News or Disinformation 2.0? Some Insights into Romanians' Digital Behaviour. Romanian Journal of European Affairs, 18(1), 24-38.

Baym, G., \& Jones, J. P. (2012). News Parody in Global Perspective: Politics, Power, and Resistance. Popular Communication, 10(1-2), 2-13. doi:10.1080/15405702.2012.638566

Berkowitz, D., \& Schwartz, D. A. (2016). Miley, CNN and The Onion. Journalism Practice, 10(1), 1-17. doi:10.1080/17512786.2015.1006933.

Brewer, P. R., Young, D. G., \& Morreale, M. (2013). The Impact of Real News about "Fake News": Intertextual Processes and Political Satire. International Journal of Public Opinion Research, 25(3), 323-343. doi:10.1093/ijpor/edt015.

Browning, N., \& Sweetser, K. D. (2014). The Let Down Effect: Satisfaction, Motivation, and Credibility Assessments of Political Infotainment. American Behavioral Scientist, 58(6), 810-826. doi:10.1177/00027 64213515227.

Butler, O., \& Clifton, J. (2017, December 6). I Made My Shed the Top Rated Restaurant On TripAdvisor. Retrieved November 18, 2018, from Vice website: https://www.vice.com/en_uk/article/434gqw/i-mademy-shed-the-top-rated-restaurant-on-tripadvisor. 
Conotter, V., Boato, G., \& Farid, H. (2010). Detecting photo manipulation on signs and billboards. 2010 IEEE International Conference on Image Processing, 1741-1744. doi:10.1109/ICIP.2010.5652906.

Cuthbertson, A. (2017). Germany Unveils Bill To Fine Social Networks Over Fake News. Retrieved November 7, 2018, from Newsweek website: https:/www.newsweek.com/germany-unveils-bill-fine-social-netw orks-fake-news-579958.

Davis, C. A., Varol, O., Ferrara, E., Flammini, A., \& Menczer, F. (2016). BotOrNot: A System to Evaluate Social Bots. Proceedings of the 25th International Conference Companion on World Wide Web - WWW '16 Companion, 273-274. doi:10.1145/2872518.2889302.

Day, A., \& Thompson, E. (2012). Live From New York, It's the Fake News! Saturday Night Live and the (Non)Politics of Parody. Popular Communication, 10(1-2), 170-182. doi:10.1080/15405702.2012.638582.

De keersmaecker, J., \& Roets, A. (2017). 'Fake news'?: incorrect, but hard to correct?: the role of cognitive ability on the impact of false information on social impressions. INTELLIGENCE, 65, 107-110. doi:10. 1016/j.intell.2017.10.005.

Dean, W. (2013). What is the purpose of journalism? Retrieved March 31, 2019, from American Press Institute website: https://www.americanpressinstitute.org/journalism-essentials/what-is-journalism/purposejournalism/.

Edelman. (2018). Edelman Trust Barometer. Retrieved November 21, 2018, from Edelman website: https://w ww.edelman.com/trust-barometer.

Finifter, A. W. (1970). Dimensions of Political Alienation. American Political Science Review, 64(2), 389-410. doi: $10.2307 / 1953840$.

Gajda, A. (2009). Judging Journalism: The Turn toward Privacy and Judicial Regulation of the Press. California Law Review, 97(4), 1039. doi:10.15779/Z387M6R.

Gelfert, A. (2018). Fake News: A Definition. Informal Logic, 38(1), 84-117. doi:10.22329/il.v38i1.5068.

High Level Expert Group on Fake News and Online Disinformation. (2018). Final report of the High Level Expert Group on Fake News and Online Disinformation. Retrieved March 24, 2019, from Digital Single Market - European Commission website: https://ec.europa.eu/digital-single-market/en/news/finalreport-high-level-expert-group-fake-news-and-online-disinformation.

Hill, A. G. (1922). The Practice of the Kansas Code of Ethics for Newspapers. The ANNALS of the American Academy of Political and Social Science, 101(1), 179-187. doi:10.1177/000271622210100127.

Hoffman, L. H., \& Young, D. G. (2011). Satire, Punch Lines, and the Nightly News: Untangling Media Effects on Political Participation. Communication Research Reports, 28(2), 159-168. doi:10.1080/08824096 .2011.565278.

Jang, M. J., \& Kim, J. K. (2018). Third person effects of fake news: Fake news regulation and media literacy interventions. doi:10.1016/j.chb.2017.11.034.

Keyes, R. (2004). The Post-Truth Era: Dishonesty and Deception in Contemporary Life. New York: St. Martin's Press.

Kucharski, A. (2016). Post-truth: Study epidemiology of fake news. Nature, 540, 525-525. doi:10.1038/540525a.

Lehmuskallio, A., Häkkinen, J., \& Seppänen, J. (2018). Photorealistic computer-generated images are difficult to distinguish from digital photographs: a case study with professional photographers and photo-editors. Visual Communication. doi:10.1177/1470357218759809.

Lewandowsky, S., Ecker, U. K. H., \& Cook, J. (2017). Beyond Misinformation: Understanding and Coping with the "Post-Truth" Era. Journal of Applied Research in Memory and Cognition, 6(4), 353-369. doi:10. 1016/j.jarmac.2017.07.008.

Marchi, R. (2012). With Facebook, Blogs, and Fake News, Teens Reject Journalistic "Objectivity." Journal of Communication Inquiry, 36(3), 246+262. doi:10.1177/0196859912458700.

McGonagle, T. (2017). "Fake news": False fears or real concerns? Netherlands Quarterly of Human Rights, 35(4), 203-209. doi:10.1177/0924051917738685.

Meixler, E. (2018). Indonesia Will Start Holding Weekly “Fake News” Briefings to Combat Misinformation. Retrieved July 11, 2018, from TIME website: http://time.com/5407798/indonesia-fake-news-briefings/.

Mourăo, R. R., \& Robertson, C. T. (2019). Fake News as Discursive Integration: An Analysis of Sites That Publish False, Misleading, Hyperpartisan and Sensational Information. Journalism Studies, O(0), 1-19. doi:10.1080/1461670X.2019.1566871. 
Nelson, M. R., \& Park, J. (2015). Publicity as Covert Marketing? The Role of Persuasion Knowledge and Ethical Perceptions on Beliefs and Credibility in a Video News Release Story. Journal of Business Ethics, 130(2), 327-341. doi:10.1007/s10551-014-2227-3.

Newman, N. (2017). Journalism, Media and Technology Trends and Predictions 2017 | Reuters Institute for the Study of Journalism. Retrieved March 30, 2019, from Digital News Project website: https://reutersins titute.politics.ox.ac.uk/our-research/journalism-media-and-technology-trends-and-predictions-2017.

Newman, N. (2019). Journalism, Media and Technology Trends and Predictions 2019. Retrieved February 11, 2019, from Digital News Report website: http://www.digitalnewsreport.org/publications/2019/journ alism-media-technology-trends-predictions-2019/.

Newman, N., Fletcher, R., Kalogeropoulos, A., Levy, D. A. L., \& Kleis Nielsen, R. (2018). Reuters Institute Digital News Report 2018. Reuters Institute.

Niemi, R. G., Craig, S. C., \& Franco, M. (1991). Measuring Internal Political Efficacy in the 1988 National Election Study. The American Political Science Review, 85(4), 1407-1413.

Pérez-Curiel, C., \& Naharro, P. L. (2019). Political influencers. A study of Donald Trump's personal brand on Twitter and its impact on the media and users. Communication \& Society, 32(1).

Reilly, I. (2018). F for Fake: Propaganda! Hoaxing! Hacking! Partisanship! and Activism! in the Fake News Ecology. The Journal of American Culture, 41(2), 139-152. doi:10.1111/jacc.12834.

Senecat, A. (2018). Les fausses informations circulent de moins en moins sur Facebook. Retrieved March 9, 2019, from https://www.lemonde.fr/les-decodeurs/article/2018/10/17/les-fausses-informations-perd ent-du-terrain-sur-facebook_5370461_4355770.html.

Shao, C., Hui, P.-M., Wang, L., Jiang, X., Flammini, A., Menczer, F., \& Ciampaglia, G. L. (2018). Anatomy of an online misinformation network. PLOS ONE, 13(4). doi:10.1371/journal.pone.0196087.

Silverman, C. (2016). This Analysis Shows How Viral Fake Election News Stories Outperformed Real News On Facebook. Retrieved November 7, 2018, from BuzzFeed News website: https://www.buzzfeednews. com/article/craigsilverman/viral-fake-election-news-outperformed-real-news-on-facebook.

Spinney, L. (2017). How Facebook, fake news and friends are warping your memory. Nature, 543(7644), 168-170. doi:10.1038/543168a.

Šram, Z. (2016). The Effects of Political Cynicism and National Siege Mentality on the Internalization of an Anti-European Sentiment. International Journal of Business and Social Research, 6(1), 22-31. doi:10. 18533/ijbsr.v6i1.858.

Ștefăniță, O., Corbu, N., \& Buturoiu, R. (2018). Fake News and the Third-Person Effect: They are More Influenced than Me and You. Journal of Media Research, 11(3(32)), 5-23. doi:10.24193/jmr.32.1.

Tandoc, E. C., Lim, Z. W., \& Ling, R. (2018). Defining “Fake News." Digital Journalism, 6(2), 137-153. doi:10.1080/21670811.2017.1360143.

Tarran, B. (2017). Why facts are not enough in the fight against fake news. Significance, 14(5), 6-7. doi:10.1111/j.1740-9713.2017.01066.x.

Thaker, A. (2018). WhatsApp is now betting on Indian primetime television to fight fake news. Retrieved March 9, 2019, from Quartz India website: https:/qz.com/india/1482656/whatsapp-launches-tv-ad-camp aign-to-fight-fake-news-in-india/.

Tsetsura, K. (2009). The Development of Public Relations in Russia: A Geopolitical Approach. In The Global Public Relations Handbook. Routledge Handbooks Online.

Tulupov, V. V. (1996). Public relations in Russia as a new social institution. Presented at the Speeches of Conference "Public Relations in Russia Today and Tomorrow", Voronezh, Russia: Voronezh State University.

Vivian, J. (2002). Yellow Journalism: Puncturing the Myths, Defining the Legacies by W. Joseph Campbell. Westport, CT: Praeger, 2001. 248 pp. American Journalism, 19(2), 99-101. doi:10.1080/08821127. 2002.10677885 .

Wardle, C. (2017). Fake news. It's complicated. Retrieved May 21, 2019, from First Draft website: https://medium.com/1st-draft/fake-news-its-complicated-d0f773766c79. 